\title{
Viability of Bovine's Strongyloidea eggs in a System of Anaerobic Biodigestion
}

\author{
MÁRCIA BOHRER MENTZ*, JOSÉ MARÍA WIEST ${ }^{* *}$ and PEDRO CABRAL GONÇALVES***
}

\begin{abstract}
Cattle Strongyloidea egg-viability was studied in closed system of anaerobic biodigestion. Two thirds of a biodigestor were filled with liquified manure from eight Hosltein cows, nacturally infected. For 10 consecutive weeks of observation, the biodigestor internal temperature varied from $24^{\circ} \mathrm{C}$ to $28^{\circ} \mathrm{C}$ and external temperature, from $26^{\circ} \mathrm{C}$ to $33^{\circ} \mathrm{C}$. All the effluent samples showed a constant $\mathrm{pH}$ of 7. The samples of the effluent were weekly collected, in a total of 10, and submitted to techniques to detect the presence and viability of the helminth eggs. It was detected a 35-day egg viability. The infective larvae of Haemonchus, Cooperia and Oesophagostomum genus were found until the 14th day of observation and the infective larvae of Trichostrongylus and Ostertagia genus, until the 35th day. Therefore, liquefied cattle manure containing Strongyloidea eggs must remain under anaerobic conditions for at least 35 days before its safe return to the environment.
\end{abstract}

Key words: Strongyloidea eggs, viability, anaerobic digestion, liquid manure.

\section{INTRODUCTION}

One of the current practices in zootechnic explotation is that of liquefaction of animal manure and residues, facilitating their removal and consequently reducing the labor force. Such a technique and the crowding of animals by confinement of a same species increase the risk of dissemination of transmitted diseases, often of subclinical character, through the animal manure and secretions, wich ultimately affects the environment.

Furthermore, space limitation leads liquefied organic matter, under composting, to remain stored for a period of time insufficient for the sanitary control. In a varety of systems consisting of liquid composting of animal, vegetable and human residues, the digestion process frequently ocurs in anaerobiosys. This means that the caloric energy and the $\mathrm{pH}$ increase to alcalinity, what is crucial to the control of the transmissible agents and potentially present in composts do not manifest themselves spontaneously.

In Brazil, there are no studies on liquefied residues and on their consequence before and after biodigestion, for animal and human health, or to the risk involved when they are employed as fertilizers and soil conditioners. In this study,

\footnotetext{
* Instituto de Ciências Básicas da Saúde - Departamento de Microbiologia - Setor de Parasitologia - Universidade Federal do Rio Grande do Sul (UFRGS), Av. Sarmento Leite, 500 - CEP 90050-170 - Porto Alegre, RS. e. mail: mbmentz@uol.com.br

** Instituto de Ciências 0e Tecnologia de Alimentos - ICTA, UFRGS.

****Faculdade de Medicina Veterinária - UFRGS.
} 
the viability of eggs from nematodes of Strongyloidea superfamily was evaluated in bovine feces. These parasites are very common in state of Rio Grande do Sul (RS), and are responsible for the disease known as gastrintestinal verminosis, one of the main causes of diminishing animal productivity. The investigation was carried out in a biodigestion system in wich the processes of fermentation and putrefaction occurs in anaerobiosys.

\section{MATERIALAND METHODS}

The experiment was conducted at the laboratory of the Veterinary School - Federal University of Rio Grande do Sul, in the summer, in a medium air temperature of $28^{\circ} \mathrm{C}$.

A 200 liter cylindric tank $(87 \mathrm{~cm}$ high, $72 \mathrm{~cm}$ diameter) was used as a biodigestor. The equipment contains a valve for the control of gas pressure in the upper part of the tank, a faucet for the removal of the material in the digestion process (laterally situated and at $30 \mathrm{~cm}$ of the bottom) and a thermometer for the measurement of the system's internal temperature (at the same point of the faucet). The digestor was installed and handled according to recomendations ${ }^{1,2}$.

The digestor was filled with $83 \mathrm{Kg}$ of manure, from eight cows of the Holland race in lactation and naturally infected with causal agents under study. The manure was collected and dissolved in water $(1: 1, \mathrm{w} / \mathrm{w})$, without hypocloride treatment, in the same day of harvesting ${ }^{3}$.

The resulting 166-liter load was kept under anaerobic biodigestion for 63 days.

From the seventh day of observation, a oneliter sample of the product, was collected and immediately subdivided into five subsamples of $200 \mathrm{ml}$ each. The weekly collections were made through the digestor faucet, always after homogeneization by manual agitation of the tank for aproximately 2 minutes. External temperature of the laboratory and the internal temperature of the digestor were registered twice a day, at 8:00 AM. and at 6:00 PM. The internal measurement were always performed at the medium part of the load, using the digestor thermometer, and sample $\mathrm{pH}$ values were assessed by using na indicator paper (MERCK).

For the recovery of the Strongyloidea eggs in the subsamples, it was used the Willis technique ${ }^{4}$ The viability of the eggs was tested through a coproculture, for the detection of the infective larvae and also the counting and generic identification of these larvae were carried out ${ }^{5,6}$.

For the quantitative analysis of the Strongyloidea eggs was used the mean, as a measurement of dispersion. The analysis of the infective larvae of Strongyloidea was made by the generic identification and expressed in percentages.

\section{RESULTS AND DISCUSSION}

During the observational period the internal temperatures were always lower than that of $35^{\circ} \mathrm{C}$ detected in a similar anaerobic process and sufficient, according to the author, for the patogenic control ${ }^{7}$. The results are also in agreement with those relative to the fermentation process $^{8}$. Accordingly, when the system is in anaerobiosys the process takes place without temperature elevation.

The $\mathrm{pH}$ value of the digestor product was found to be 7.0, in all weekly collections. This indicates that the biologic degradation of the mixture ocurred in anaerobiosys, since there was no alteration of the $\mathrm{pH}$ during the putrefaction process, as it was already noted in another study ${ }^{9}$. It was observed that a $\mathrm{pH}$ over 9.0 destroys certain bacterian agents ${ }^{10}$. In the case of parasites agents, the $\mathrm{pH}$ values between 5.0 and 8.5 do not affect the survival of the Strongyloidea infecting larvae, but interfere in the increase of the eclosion rate of this evolution phase ${ }^{11-14}$.

Table 1 shows the results concerning the variation of the average number of Strongyloidea

Table 1. Weekly variation in the mean value and range of Strongyloidea eggs from five fecal samples of $8 \mathrm{~g}$, collected from cattle manure kept in an anerobic biodigestor

\begin{tabular}{lcc}
\hline Week & Mean value & Variation \\
\hline 0 & 4 & $2-5$ \\
1 & 3 & $1-6$ \\
2 & 1,4 & $0-4$ \\
3 & 1,6 & $0-3$ \\
4 & 0,8 & $0-2$ \\
5 & 0,2 & $0-1$ \\
$6 *$ & 0,6 & $0-2$ \\
$7 *$ & 0,2 & $0-1$ \\
8 & 0 & 0 \\
\hline
\end{tabular}

*All eggs presented morphologycal alterations. 
eggs in relation to the longevity in a closed system of anaerobic biodigestion in five weekly-taken subsamples of the mixture.

Concerning Strongyloidea eggs, the product of this system became negative on the 35 th day of observation. These results differ from another experiments in wich even at lower temperatures $\left(18^{\circ} \mathrm{C}\right.$ to $\left.22^{\circ} \mathrm{C}\right)$ it was obtained a lower survival time for eggs of the Trichostrongylus colubriformes, Cooperia punctata, Ostertagia ostertagi species and of the Strongyloides genus - between 7 and 28 days, in liquefied manure ${ }^{15-17}$. These authors managed to increase the longevity of the Strongyloidea eggs from 64 to 172 days respectively, only when the manure temperatures lowered to $8^{\circ} \mathrm{C}$ and $3^{\circ} \mathrm{C}$.

An internal temperature of $27^{\circ} \mathrm{C}$, so close to that observed in this study, also obtained different results, with only 25 days of survival for eggs of the Cooperia curticei species ${ }^{18}$.

Increased liquefied manure temperature to $35^{\circ} \mathrm{C}$, through aerobic fermentation obtained a reduction in the survival time of the tricostrongilid $\mathrm{s}$ eggs to 10 days $^{19}$.

Other authors also observed a reduction in the survival time of parasite agents to 30 and zero days, respectively. In temperatures that ranged from $32^{\circ} \mathrm{C}$ to $56^{\circ} \mathrm{C}$, but obtained only through aeration and forced movimentation of the organic material ${ }^{20-25}$.

In this experiment the results concerning temperature and $\mathrm{pH}$ agree with those wich proved that the residues of liquefaction do not increase spontaneously the temperature of the mixture, thus promoting the preservation of the existing pathogens ${ }^{26,10}$.

The results concerning the eggs longevity in a closed anaerobic digestion system of five weekly-taken subsamples of the liquefied manure are shown in Table 2.
In the present work, infecting larvae belonged to the Haemonchus, Ostertagia, Trichostrongylus, Cooperia and Oesophagostomum genera.

From the 35th day, there were no infecting larvae of any of the genera studied, even though the eggs had shown structural modifications only after the $42^{\text {nd }}$ day of observation, with an avarage internal temperature of $26^{\circ} \mathrm{C}$.

The infecting larvae of the Haemonchus genus appeared in samples collected on the 7th day of observation. Concerning longevity a study obtained a larger survival in water of the infecting larvae of the Haemonchus genus (98 to 280 days), at temperature between $0^{\circ} \mathrm{C}$ and $30^{\circ} \mathrm{C}$, respectively ${ }^{27,28}$.

This includes the temperature range obtained in this experiment, wich varied from $24^{\circ} \mathrm{C}$ to $28^{\circ} \mathrm{C}$. The discrepant results obtained by these authors could be related to the vehicle used water.

In this study, the infecting larvae of Cooperia and Ostertagia genera were detected on the $7 \mathrm{ht}$ and 21th day, respectively. Different results were showned a lower temperature $\left(20^{\circ} \mathrm{C}\right)$, with a maximum survival of 28 days for the same genus and environment ${ }^{16}$.

Still concerning the infecting larvae of the Ostertagia and Trichostrongylus genera, they were detected more frequently and recovered for a longer period of time. This coincides partially with other results in wich observed a larvae frequency of $O$. ostertagi and Cooperia oncophora species in similar conditions as this experiment ${ }^{29}$. In different environment, such as excremental matter and pasture the infecting larvae of Cooperia species had a larger frequency and resistance ${ }^{30,31}$.

Therefore, the survival time of infecting larvae of the $O$. ostertagi and $C$. oncophora species was reduced by increasing the temperature of the

Table 2. Comparison of variation in the percentage of Strongyloidea infective larvae from bovines in 5 subsamples of $80 \mathrm{~g}$ from the efluent and the time spent in a closed anaerobic biodigestion system

\begin{tabular}{lrrrrrrrrrr}
\hline & \multicolumn{1}{c}{ Day of observation } & \multicolumn{1}{c}{} \\
Genus / L2i & 0 & 7 & 14 & 21 & 28 & 35 & 42 & 49 & 56 & 63 \\
\hline Haemonchus & 4 & 2 & 0 & 0 & 0 & 0 & 0 & 0 & 0 & 0 \\
Ostertagia & 0 & 12 & 23 & 33 & 6 & 0 & 0 & 0 & 0 & 0 \\
Trichostrongylus & 58 & 83 & 77 & 67 & 20 & 0 & 0 & 0 & 0 & 0 \\
Cooperia & 5 & 1 & 0 & 0 & 0 & 0 & 0 & 0 & 0 & 0 \\
Oesophagostomum & 13 & 2 & 0 & 0 & 0 & 0 & 0 & 0 & 0 & 0 \\
\hline
\end{tabular}


liquefied manure to $56^{\circ} \mathrm{C}$, through the utilization of the Licom moving system and forced aeration, since the temperature elevation in the liquefied manure did not occur spontaneously ${ }^{22}$.

In this study, the infecting larvae of Trichostrongylus species were found on the 28th day of observation, with an avarage internal temperature of $26^{\circ} \mathrm{C}$. This agrees with other experiment wich considers the temperature between $20^{\circ} \mathrm{C}$ and $30^{\circ} \mathrm{C}$ as ideal for the "in vitro" development of the Trichostrongylus axei and T. colubriformis species $^{32}$.

In this study, the infecting larvae of the Oesophagostomum genus were found on the 7th day of observation, with an avarage temperature of $26^{\circ} \mathrm{C}$. Different results were obtained in another study with a survival time of 43 days in a temperature of $22^{\circ} \mathrm{C}$ in an anaerobic environment. 16 It should be emphasized that here, although the temperature difference had been of only $4^{\circ} \mathrm{C}$, the survival time was reduced.

Finally, all the eggs found in this experiment, begining on the 35th day of observation, were non-viable, since they presented structural modifications, such as morula alteration and one third reduction of its size. This partially explains, the lack viability of the eggs. Such findings contradict the results obtained in another experiment wich registered the lack viability of the parasites stating at the seventh day, in temperatures between $18^{\circ} \mathrm{C}$ and $26^{\circ} \mathrm{C}^{33}$. The authors related these findings to the hypotheses of the presence of the putrefactives bacteria and oxygen reduction in the liquefied manure in anaerobiosys.

The results concerning the viability of the studied parasites agents coincide with the hypothesis that the processes of fermentation and putrefaction in the system of liquid compostation were directly proportionate to anaerobiosys and inversely proportional to the pathogenes ${ }^{7}$.

There are suggest that the liquefied animal residues do not produce, by themselves, temperatures capable of controlling pathogens during their storages ${ }^{9}$.

The results obtained through experimentation allow the conclusion that the viability of Strongyloidea eggs was of 35 days. The infecting larvae of the Haemonchus, Cooperia and Oesophagostomum genera were controllable after 14 days of storage and those of Ostertagia and Trichostrongylus genera, after 35 days.
The most resistant infecting larvae in the studied environment were, in a decreasing order, of helmints of the Trichostrongylus, Ostertagia, Haemonchus, Cooperia and Oesophagostomum genera.

Hence, in order to allow the utilization of manure from Strongyloidea helminthus superfamily - parasited bovines without risks to animals health, composting should not be made "in natura" over the soil or pasture. The retention period of the anaerobic digestão product should be of at least 35 days before it be returned to the environment.

\section{RESUMEN}

El objectivo deste estudio fué evaluar la viabilidad de huevos de Strongyloidea de bovinos en un sistema cerrado de biodigestión anaerobia. Dos partes del biodigestor fueran completadas con estiércol liquido de ocho vacas Holstein Breed, naturalmente infectadas con los parásitos estudiados. Durante 10 semanas consecutivas de observación, la temperatura interna del tanque varió de $24^{\circ}$ hasta $28^{\circ} \mathrm{C}$ y, externamente, de $26^{\circ}$ hasta $33^{\circ} \mathrm{C}$. El pH medido fué siempre7. Se examinaran las muestras del efluente semanalmente, en un total de 10, las cuales fueran submetidas a técnicas para detección de la existencia y viabilidad de huevos de helmintos. Se observó que los huevos de Strongyloidea tuvieran viabilidad por 35 días. Se encontraran las larvas infectivas de los generos Haemonchus, Cooperia y Oesophagostomum hasta el $14^{\circ}$ día de observación y las del Trichostrongylus y Ostertagia hasta el $35^{\circ}$ día. Los datos obtenidos muestran que el estiércol líquido bovino, infectado con huevos de Strongyloidea, deverán ser mantenidos en biodigestión anaerobia por 35 días, por lo menos, antes de su retorno al medio ambiente.

\section{REFERENCES}

1.- EMATER. Biogás, a solução para obter energia e luz no meio rural. Lavoura Pecuária 1980; 30-2.

2.- SOARES F S. Biodigestor: uma alternativa energética. A Hora Veterinária 1881; 2: 12-6.

3.- SILVA N A. Manual do biodigestor, modelo chinês. Brasília, EMBRATER, 1980.

4.- WILLIS H H. A simple levitation method for the detection of hookworm ova. Med J Austral Glebe 1921; 8: 375-6.

5.- ROBERT'S F H S, O'SULLIVAN S P. Methods for eggs counts and larval cultures for Strongyles infesting 
the gastro-intestinal tract of cattle. Austr J Agri Res 1950; 1: 99.

6.- KEITH R K. The differentiation of the infective larval of some commom nematode parasites of Cattle. Austr J Zool 1953; 1: 223.

7.- SILVA E J. Biogas Generation: developments, problems, and tasks: an overview. In: CONFERENCE OF THE STATE OF THE ART OF BIOCONVERSION OF ORGANIC RESIDUES FOR RURAL COMMUNITIES, 1978. Proc Inst Nutrition of central America and Panama. 1978; p. 72-83.

8.- WIEST J M. Biodigestores: a importância em saúde animal e saúde pública e alternativas para o seu controle sanitário. A Hora Veterinária 1982; 1: 21-7.

9.- WIEST J M. Controle Sanitário da Matéria Orgânica. Arq Fac Vet da UFRGS 1982/83; 10-11, 35-44.

10.- STRAUCH D. Animal production and environmental health. (World Animal Science, B 6). Amsterdan. Elsevier Science Publishers BV, 1987. 324p.

11.- PECHEUR M. Étude de l' influence du pH et l' àction de la cyanamide calcique sur les oeufs et les larves de Trichostrongylus et de Strongyloides. Ann Med Vet 1962; 106: 18-41.

12.- MISRA S C, RUPRAH N S. Effects of temperature, relative humidity and $\mathrm{pH}$ on Haemonchus contortus eggs. Ind Vet J 1973; 50: 136-42.

13.- DICK J W, LELAND Jr, S E. The influence of $\mathrm{pH}$ on the in vitro development of Cooperia punctata (Ranson, 1907). J Parasitol 1973; 59: 770-5.

14.- NETTO F G S. Influência da temperatura e do pH na obtenção in vitro de larvas infectantes de nematódeos gastrintestinais de ovinos. Dissertação de mestrado. Faculdade de Medicina Veterinária, Universidade Federal do Rio Grande do Sul, 1988. Porto Alegre. 86p.

15.- ENIGK K, HILDEBRANT J, TIETJEN C. Die Lebensdauer von Helmintheneiern und-Larven in Schwemmist. Berliner und Munchener Tierarztliche Wochenschrift 1965; 78: 102-6.

16.- PERSSON L. Studies on the survival of eggs and infective Larvae of Ostetagia ostertagi and Cooperia oncophora in liquid cattle manure. Zbl r Vet Med 1974; 21: 311-7.

17.- MARTI O G, BOORAM C V, HALE O L. Survival of eggs and larvae of Swine nematodes parasites in aerobic and anaerobic waste treatment systems. J Environ Quality 1980; 9: 401-4.

18.- AHLUWALIA J S. Survival of eggs free-living stages of Cooperia curticei (Ranson, 1907) at controlled temperatures. Ind Vet J1974; 51: 219-23.

19.- ENIGK K, THAER R, DEY-HAZRA A, AHLERS R. Die überensfahigkeit Parasitärer Dauerformen bei der Fermentation von Rinderflüssigmist unter erhöhten
Temperaturen. Zentralblatt für Veterinär Medizin 1975; 22: 687-702.

20.- SP ENGLER R. Die lebensfähigkeit von eiern und larven der wichtigsten wurmparasiten unserer haustiere an futtermitteln vor und nach der trocknung. Dissertation, 1955, Munchen.

21.- PREMVATI, NARAIN B. Effect of temperature hatching and viability of the eggs of Bunostomum trigonocephalum (Rudolphi, 1908). Parasitology 1969; 59: 185-91.

22.- PERSSON L. The destruction of parasites in liquid cattle manure by aeration using the Licom system. Zbt Vet Med 1973; 20: 289-303.

23.- ENIGK K. Verbreitung freilebender Entwicklungsformen von Parasiten durch Siedlungsabwasser. Deutsche Tierärztliche Wochenschrift 1980a; 87: 35393.

24.- ENIGK K. Vernichtung parasitarer Entwicklungsformen in Flussigmist. Berliner und Munchener Tierärztliche Wochenschrift 1980b; 93: 379-384.

25.- WIEST J M, MENTZ M B, PIANTA C. Compostação de dejetos animais sólidos em condições de outono em Porto Alegre. Arq Fac Vet da UFRGS 1985; 13: 29-41.

26.- WIEST J M. Saneamento no meio rural: III - Sistema integrado para o tratamento de biomassas liquefeitas. Arq Fac Vet da UFRGS 1980; 8: 36-70.

27.- TRIPHATHI J C. Effect of different temperatures on infective larvae of Haemonchus contortus under laboratory conditions. Ind J Anim Sci 1977; 47: 73942.

28.- MISRA S C. A note on in vitro effects of temperature on the survival of Haemonchus contortus infective larvae. Ind J Anim Sci 1978; 48: 322-3.

29.- MOORE J F. Occurence of Trichostrongylid Nematodes in cattle slurry. Irish J Agricul Res 1978; 17: 255-66.

30.- ZOCOLLER M C, MACHADO R Z, STARKE W A. Desenvolvimento e sobrevivência de ovos e de larvas de nematódeos gastrintestinais de bovinos, nas pastagens de Cerrado, município de Selvíria, MS. In: SEMINÁRIO BRASILEIRO DE PARASITOLOGIA VETERINÁRIA. Anais CBPV. 1989; p. 21.

31.- LIMA W S, GUIMARÃES. Comportamento e sobrevivência dos estádios de vida-livre de helmintos gastrintestinais de bovinos no Vale do Rio Doce - MG. In: SEMINÁRIO BRASILEIRO DE PARASITOLOGIA VETERINÁRIA. Anais CBPV. 1989; p. 20.

32.- VASQUES F A R. Effect of temperature on the development of pre-parasitic Stages of Trichostrongylus axei na T. colubriformis. Rev Iber Parasitol 1976; 36: 249-55.

33.- ZAJICEK D, BISCHOFOVA N, BENDA J. Survival of parasite eggs and cysts in stored liquid manure. Vet Med 1980; 25: 213-22. 